\title{
SISTEM PENDUKUNG KEPUTUSAN PEMBERIAN KREDIT MENGGUNAKAN METODE ANALYTICAL HIERARCHY PROCESS PADA BANK PERKREDITAN RAKYAT (BPR) BATANG TARUSAN
}

\author{
Dodi Guswandi \\ Universitas Putra Indonesia YPTK Padang \\ E-mail : guswandidodi@yahoo.co.id
}

\begin{abstract}
The rapidly technology process on globalisasion era in business world, makes the decision making is the important thing to make decision faced with the competition in business world. The decision making can be influence by a few aspect and group, which can influence the decision maker to accelerate the fast, perfectly and correctly the decision making. This software created by using Analytical Hierarchy Process method. Where this algorithm do the process of calculating to get the best decision, using the score group of calculation and compare it with each possibility count of the choosen decision. This software specially will be use to decision support in present credit to PT. BPR Batang Tarusan.From design and the testing the application of decision support system result a correct and flexible decision with all criteria which influence that decision and give a report in order to director can understand why this software choose that decision.
\end{abstract}

Keywords: Analytical Hierarchy Process, AHP, Decision Support System, DSS.

\section{Pendahuluan}

Kebutuhan manusia di era sekarang telah dipengaruhi oleh alat-alat elektronik yang semakin canggih. Apakah pada hal-hal yang menyangkut kebutuhan informasi, teknologi, kemudahan pekerjaan, atau yang lainnya. Salah satu komponen elektronik yang sangat mempengaruhi perkembangan alat-alat elektronik adalah komputer, yaitu seperangkat alat-alat elektronik yang terintegrasi dalam sebuah sistem yang dapat melakukan tugas-tugas yang telah diprogramkan kepadanya untuk dijalankan yang juga dikenal dengan istilah Personal Computer (PC).

Sistem Penunjang Keputusan mendayagunakan sumber daya individu-individu secara intelek dengan kemampuan komputer untuk meningkatkan kualitas keputusan. Jadi ini merupakan Sistem Penunjang Keputusan yang berbasis komputer untuk manajemen pengambilan keputusan yang berhubungan dengan masalah-masalah semi terstruktur (Irfan Subakti, 2002).

Sistem Penunjang Keputusan dapat dimanfaatkan untuk menganalisis pemberian kredit kepada masyarakat sehingga proses pengambilan keputusan oleh pihak Bank menjadi lebih akurat. Selama ini, pemberian kredit terhadap masyarakat dilakukan secara manual dengan mengisi lembaran surat permohonan dan persyaratan kredit oleh debitur Kemudian lembaran itu diberikan kepada pihak account officer yang mengentrikan secara manual mengahasilkan output daftar pemohon kredit, kemudian dilberikan langsung kepada atasan untuk di acc.

Jika dilihat dari sistem yang sedang berjalan, pengambilan keputusan masih dilakukan secara manual, penyimpanan data yang masih belum elektronik dan memanfaatkan database sehingga redundancy data masih sering terjadi, sulitnya dalam pencarian satu data juga menjadi kendala, dan para debitur dalam pengisian persyaratan kredit banyak yang tidak sesuai dengan data yang sebenarnya. Sehingga seorang atasan dalam pengambilan keputusan mendapatkan kesulitan. 


\section{Tinjauan Literatur Sistem Pendukung Keputusan}

Sistem pendukung keputusan adalah sistem penghasil informasi yang ditujukan pada suatu masalah tertentu yang harus dipecahkan oleh manager dan dapat membantu manager dalam pengambilan keputusan (Raymond Mc Leod Jr., 1995:348).

Sistem pendukung keputusan merupakan sistem informasi pada level manajemen dari suatu organisasi yang mengkombinasikan data dan model analisis canggih atau peralatan data analisis untuk mendukung pengambilan keputusan keputusan yang semi terstruktur dan tidak terstruktur (Hanif Al Fatta, 2007) [4].

Menurut Simon dalam bukunya terbitan 1977, menguraikan istilah keputusan menjadi keputusan terprogram dan keputusan tak terprogram. Keputusan terprogram yaitu bersifat berulang-ulang dan rutin. Pada suatu tingkat tertentu dan prosedur telah ditetapkan untuk menanganinya sehingga ia dianggap suatu denovo (yang baru) setiap kali terjadi. Keputusan tak terprogram yaitu bersifat baru, tidak terstruktur, dan biasanya tidak larut.

\section{Tahapan Pengambilan Keputusan}

Saat melakukan pemodelan dalam pembangunan DSS dilakukan langkah-langkah (Kusrini. 2007), yaitu sebagai berikut :

a. Studi Kelayakan (Intelligence)

Pada langkah ini, sasaran ditentukan dan dilakukan pencarian prosedur, pengumpulan data, identifikasi masalah, identifikasi kepemilikan masalah, klasifikasi masalah, hingga akhirnya terbentuk sebuah pernyataan masalah.

b. Perancangan (Design)

Pada tahapan ini akan diformulasikan model yang akan digunakan dan kriteria-kriteria yang ditentukan. Setelah itu, dicari alternatif model yang bisa menyelesaikan permasalahan tersebut. Langkah selanjutnya adalah memprediksi keluaran yang mungkin. Kemudian ditentukan variabelvariabel model.

c. Pemilihan (Choice)

Setelah pada tahap perancangan ditentukan berbagai alternatif model berserta variable-variabelnya. Pada tahapan ini akan dilakukan pemilihan modelnya,

d. Membuat DSS

Setelah menentukan modelnya, berikutnya adalah mengimplementasikannya dalam aplikasi DSS [5].

\section{Komponen-Komponen Sistem Pendukung Keputusan (SPK).}

Turban (1998) mengemukakan bahwa sebuah system pendukung keputusan dibangun dari beberapa subsistem, antara lain :

a. Subsistem manajemen data, meliputi basis data yang mengandung data yang relevan dengan keadaan yang ada dan dikelola oleh sebuah sistem yang dikenal sebagai Database Management System (DBMS).

b. Subsistem manajemen model, yaitu sebuah paket perangkat lunak yang berisi model-model finansial, statistik, management science, atau model kuantitatif yang lain yang menyediakan kemampuan analisis sistem dan management software yang terkait.

c. Subsistem manajemen pengetahuan (knowledge) yaitu subsistem yang mampu mendukung subsistem yang lain atau berlaku sebagai sebuah komponen yang berdiri sendiri (independen).

d. Subsistem antarmuka pengguna (User Interface), yang merupakan media tempat komunikasi antara pengguna dan sistem pendukung keputusan serta tempat pengguna memberikan perintah kepada sistem pendukung keputusan. 


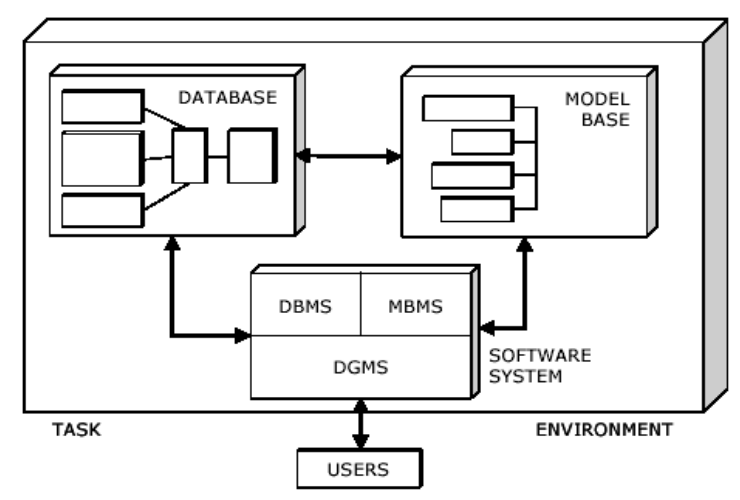

Gambar 2.1 : Komponen SPK

\section{Analytical Hierarchy Process (AHP)}

Metode AHP dikembangkan oleh Saaty dan dipergunakan untuk menyelesaikan permasalahan yang komplek dimana data dan informasi statistik dari masalah yang dihadapi sangat sedikit.

Metode SAW sering juga dikenal istilah metode penjumlahan analytical Hierarchy process (AHP) adalah salah satu bentuk model pengambilan keputusan dengan multiple criteria. Salah satu kehandalan AHP adalah dapat melakukan analisis secara simultan dan terintegrasi antara parameterparameter yang kualitatif atau bahkan yang kuantitatif. Peralatan utama dari model ini adalah sebuah hirarki fungsional dengan input utamanya persepsi manusia. Suatu masalah yang kompleks dan tidak terstruktur dipecah kedalam kelompok-kelompoknya dan kelompok-kelompok tersebut menjadi suatu bentuk hirarki.

Langkah-langkah yang dilakukan dalam metode AHP sebagai berikut :

1. Mendefinisikan masalah dan menentukan solusi yang diinginkan, lalu menyusun hierarki dari permasalahan yang dihadapi. Penyusunan hierarki adalah dengan menetapkan tujuan yang merupakan sasaran sistem secara keseluruhan pada level terbatas.

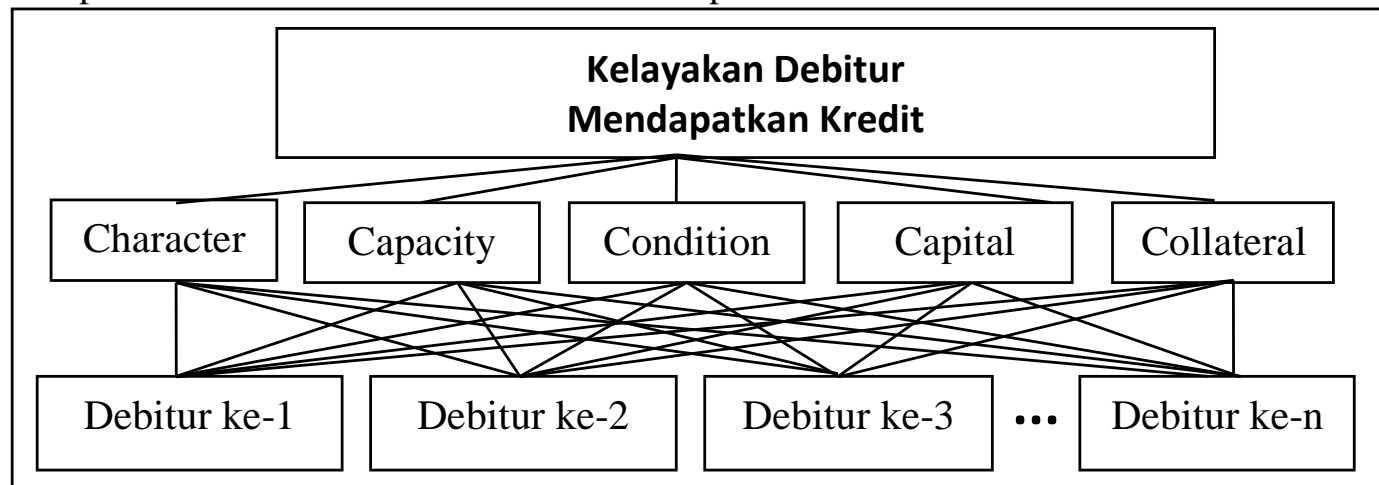

Gambar 2.1 Struktur Hirarki AHP pada Sistem Pendukung Keputusan Penilaian Pemberian Kredit

Keterangan Gambar 3.9 :

a. Hirarki terbawah adalah nama-nama debitur yang mengajukan permohonan kredit.

b. Hirarki kedua adalah kriteria-kriteria yang dipakai untuk menganalisis debitur.

c. Hirarki ketiga adalah hirarki yang berisi debitur dengan memenuhi syarat mendapatkan kredit.

2. Menentukan Prioritas Elemen

a. Langkah pertama dalam menentukan prioritas elemen adalah membuat perbandingan pasangan, yaitu membandingkan elemen secara berpasangan sesuai kriteria yang diberikan.

b. Matriks perbandingan berpasangan diisi menggunakan bilangan untuk merepresentasikan

3. Sintesis kepentingan relatif dari suatu elemen terhadap elemen yang lainnya. 
Pertimbangan-pertimbangan terhadap perbandingan berpasangan disintesis untuk memperoleh keseluruhan prioritas. Hal-hal yang dilakukan dalam langkah ini adalah :

a. Menentukan nilai prioritas Kriteria Penilaian

b. Membuat table perbandingan prioritas setiap Kriteria Penilaian dengan membandingkan masing-masing Kriteria Penilaian.

c. Menentukan bobot pada tiap Kriteria Penilaian

d. Mencari nilai bobot untuk masing-masing Kriteria Penilaian.

4. Mengukur Konsistensi

Dalam pembuatan keputusan, penting untuk mengetahui seberapa baik konsistensi yang ada, karena kita tidak menginginkan keputusan berdasarkan pertimbangan dengan konsisten yang rendah. Hal-hal yang dilakukan dalam langkah ini adalah :

a. Kalikan setiap nilai pada kolom pertama dengan prioritas relatif elemen pertama, nilai pada kolom kedua dengan prioritas relatif elemen kedua, dan seterusnya.

b. Jumlahkan setiap baris.

c. Hasil dari penjumlahan baris dibagi dengan elemen prioritas relatif yang bersangkutan.

d. Jumlahkan hasil bagi di atas dengan banyaknya elemen yang ada, hasilnya disebut $\lambda$ maks.

5. Hitung Consistency Index (CI), dengan rumus :

$C I=(\lambda$ maks-n $) / n$

Dimana $\mathrm{n}=$ banyaknya elemen

6. Hitung Rasio Konsistensi/ Consistency Ratio (CR) dengan rumus :

$C R=C I / I R$

dimana $: C R=$ Consistency Ratio

$C I=$ Consistency Index

$I R=$ Indeks Random Consistency

7. Memeriksa Konsistensi Hirarki. Jika nilainya lebih dari $10 \%$, maka penilaian data judgment harus diperbaiki. Namun jika rasio konsistensi $(C I / C R)$ kurang atau sama dengan 0,1, maka hasil perhitungan bisa dinyatakan benar. Daftar Index Random Consistention (IR) bisa dilihat dalam Tabel 2.1 berikut.

\begin{tabular}{|c|c|c|c|c|c|c|c|c|c|c|c|}
\hline $\mathrm{n}$ & 1 & 2 & 3 & 4 & 5 & 6 & 7 & 8 & 9 & 10 & 11 \\
\hline R.I. & 0.00 & 0.00 & 0.58 & 0.90 & 1.12 & 1.24 & 1.32 & 1.41 & 1.45 & 1.49 & 1.51 \\
\hline
\end{tabular}

\section{Metodologi}

Untuk memberikan panduan dalam penyusunan penelitian ini maka perlu adanya metodologi penelitian dan kerangka kerja penelitian yang digunakan.

1. Mengidentifikasi Ruang Lingkup Masalah

Ruang lingkup masalah yang diteliti harus ditentukan terlebih dahulu karena tahapan identifikasi masalah dimulai dengan mempelajari mulai dari pengumpuan data siswa, kemudian analisa data siswa yang ikut ujian, terlambat, hingga yang tidak ikut ujian.

2. Mengumpulkan Data

Dalam tahap ini pengumpulan data dilakukan dengan cara langsung observasi pada Kecamatan Koto XI Tarusan, data yang dikumpulkan adalah data-data penjualan. Setelah data-data tersebut dikumpulkan dan dipelajari maka langkah selanjutnya yang dilakukan adalah melakukan pengelompokkan data rumah tangga miskin yang tidak layak hunidan dari hasil pengelompokkan data tersebut maka dapat memutuskan masalah-masalah yang akan dipecahkan, dan mencari solusinya.

3. Menganalisa Sistem

Analisis sistem (system analysis) dapat didefinisikan sebagai penguraian dari suatu system informasi yang utuh kedalam bagian-bagian komponennya dengan maksud untuk mengidentifikasikan dan mengevaluasi permasalahan-permasalahan, kesempatan-kesempatan, 
hambatan-hambatan yang terjadi dan kebutuhan-kebutuhan yang diharapkan sehingga dapat diusulkan perbaikan-perbaikannya.

a) Menganalisa Masalah

Bantuan bedah rumah merupakan bantuan yang diberikan kepada masyarakat Rumah Tangga Miskin (RTM), bantuan yang diberikan berasal dari upaya Badan Amil Zakat (BAZ) yang melakukan pemungutan zakat dari pegawai negeri sipil untuk disalurkan kepada masyarakat kurang mampu. Bantuan bedah rumah ini dilakukan untuk meningkatkan kesejahteraan masyarakat yang kurang mampu terutama keluarga yang mempunyai anak dalam masa pendidikan sekolah. Dalam proses pengambilan keputusan oleh pimpinan yang dilakukan secara manual, proses yang dilakukan dalam pengambilan keputusan membutuhkan tenaga dan waktu yang lama.

Dari ditemukan masalah tersebut, maka dibuatlah suatu Sistem Pendukung Pengambilan Keputusan Menggunakan Basis Data Simple Additive Weighting Membantu dalam pengambilan keputusan. Pada sistem yang dibangun, user disediakan alternatif dalam memilih kriteria yang sesuai, kemudian system akan mengolah dan memberikan alternatif data siswa yang sesuai dengan kriteria pilihan user. Pada analisis masalah sistem pendukung keputusan dengan basis data Simple Additive Weighting, awalnya pengambil keputusan memilih terlebih dahulu obyek yang akan diseleksi, kemudian membuat beberapa kriteria untuk digunakan dalam penyeleksian dan menentukan dominasi kriteria dan nilai preferensinya.

b) Menganalisa Kebutuhan Non-Fungsional

Analisis non fungsional dilakukan untuk menghasilkan spesifikasi kebutuhan non fungsional. Spesifikasi kebutuhan non fungsional adalah spesifikasi yang rinci tentang hal-hal yang akan dilakukan system ketika diimplementasikan.Analisis kebutuhan ini diperlukan untuk menentukan keluaran yang akan dihasilkan sistem, masukan yang diperlukan sistem, lingkup proses yang digunakan untuk mengolah masukan menjadi keluaran, volume data yang akan ditangani sistem, jumlah pemakai dan kategori pemakai, serta kontrol terhadap sistem.

4. Menguji Sistem

Pengujian sistem dilakukan dalam bentuk konsep dari perancangan sistem pendukung keputusan dalam menentukan bantuan bedah rumah, sesuai dengan ketentuan dari pihak yang terkait.

5. Mengimplementasi Sistem

Pada tahap ini dilakukan pengkajian kembali kelayakan dari pada system pendukung keputusan yang telah dirancang. Apakah system tersebut sudah sesuai atau masih perlu dilakukan peninjauan kembali atau dilakukan perbaikan.

6. Menarik Kesimpulan

Setelah implementasi sistem dilakukan dan hasil yang diinginkan telah sesuai dengan alnalisis metode yang digunakan, maka dapat ditarik sebuah kesimpulan bahwa metode simple additive weighting tepat digunakan dalam permasalahan dalam proses pengambilan keputusan bedah rumah.

\section{Analisa Pembahasan dan Hasil}

Langkah-langkah yang harus dilakukan untuk menentukan pemberian kredit dengan metode Analytical Hierarchy Process (AHP) adalah membuat form untuk menentukan nilai prioritas kriteria, dimana terdapat beberapa tahapan yang harus dilakukan dalam menentukan nilai prioritas kriteria, yaitu:

a. Menentukan nilai prioritas kriteria penilaian.

Biasanya orang lebih mudah mengatakan bahwa kriteria penilaian Character lebih penting dari pada kriteria penilaian Capacity, kriteria Capacity kurang penting dibanding dengan kriteria Condition dan sebagainya, namun mengalami kesulitan menyebutkan seberapa penting kriteria Character dibandingkan kriteria Capacity atau seberapa kurang pentingnya kriteria Capacity dibandingkan 
dengan kriteria Condition. Untuk itu perlu membuat tabel konversi dari pernyataan prioritas ke dalam angka-angka. Tabel skala nilai prioritas kriteria penilaian seperti pada tabel dibawah ini :

Tabel 4.1 Skala Nilai Prioritas KPI

\begin{tabular}{|c|l|}
\hline Skala & \multicolumn{1}{|c|}{ Definisi dari "Importance" } \\
\hline 1 & KPI Character sama penting dibanding dengan KPI Capacity \\
3 & KPI Character sedikit lebih penting dibanding dengan KPI Capacity \\
5 & KPI Character lebih penting dibanding dengan KPI Capacity \\
7 & KPI Character sangat penting dibanding dengan KPI Capacity \\
9 & KPI Character jauh sangat penting dibanding dengan KPI Capacity \\
\hline $2,4,6,8$ & $*$ ) nilai tengah-tengah \\
\hline
\end{tabular}

*) Pengertian nilai tengah-tengah adalah jika KPI Character sedikit lebih penting dari KPI Capacity maka kita seharusnya memberikan nilai 3, namun jika nilai 3 tersebut dianggap masih terlalu besar dan nilai 1 masih terlalu kecil maka nilai 2 yang harus kita berikan untuk prioritas antaraa KPI Character dengan KPI Capacity

*) Tabel diatas tidak disebutkan konversi nilai KPI Character kurang penting dari KPI Capacity karena pernyataan KPI Character kurang penting dari KPI Capacity sama dengan pernyataan nilai KPI Capacity lebih penting dari KPI Character.

b. Matriks perbandingan berpasangan antar kriteria.

Proses membandingkan antar kriteria penilaian (KPI) sebagai berikut :

Tabel 4.2 Perbandingan Prioritas Setiap KPI

\begin{tabular}{|c|c|c|c|c|c|}
\hline & Character & Capacity & Condition & Capital & Collateral \\
\hline Character & 1 & 2 & 3 & 3 & 5 \\
\hline Capacity & 0.5 & 1 & 3 & 3 & 5 \\
\hline Condition & 0.33 & 0.33 & 1 & 2 & 3 \\
\hline Capital & 0.33 & 0.33 & 0.5 & 1 & 3 \\
\hline Collateral & 0.2 & 0.2 & 0.33 & 0.33 & 1 \\
\hline Jumlah & $\mathbf{2 . 3 6}$ & $\mathbf{3 . 8 6}$ & $\mathbf{7 . 8 3}$ & $\mathbf{9 . 3 3}$ & $\mathbf{1 7}$ \\
\hline
\end{tabular}

Cara mengisinya adalah dengan menganalisa prioritas antara KPI baris dibandingkan dengan KPI kolom. Dalam prakteknya hanya perlu menganalisa prioritas KPI yang terdapat dibawah pada garis diagonal. Hal ini sesuai dengan persamaan matematika yang menyebutnya jika $A: B=X$, maka $\mathrm{B}: \mathrm{A}=1 / \mathrm{X}$. Contoh : jika prioritas KPI Capacity (baris) : KPI Character $($ kolom $)=2$, maka prioritas KPI Character (baris) : KPI Capacity (kolom) $=1 / 2$ (lihat rumus persamaan perbandingan diatas). Sehingga prioritas setiap KPI antara KPI Character : KPI Character $=1$, KPI Condition : KPI Character $=0.33$, KPI Condition $:$ KPI Capacity $=0.33$, KPI Capital $:$ KPI Character $=0.33$, KPI Capital : KPI Collateral $=3$, KPI Collateral $:$ KPI Capacity $=0.2$.

c. Penghitungan matriks bobot nilai antar kriteria dan prioritas

Nilai bobot ini berkisar antara 0-1 dan total bobot untuk setiap kolom adalah 1. Cara menghitung bobot adalah angka pada setiap kotak dibagi dengan penjumlahan semua angka dalam kolom yang sama. Contoh bobot dari (KPI Character, KPI Character) $=1 / 2.36$ (Jumlah Kolom kriteria Character $)=0.424,($ KPI Capacity, KPI Character $)=0.5 / 2.36($ Jumlah Kolom kriteria Character $)=$ 0.212. Dengan perhitungan yang sama bobot prioritas tabel KPI diatas menjadi :

Tabel 4.3 Nilai Bobot Pada Tiap KPI

\begin{tabular}{|c|c|c|c|c|c|c|c|}
\hline & Character & Capacity & Condition & Capital & Collateral & Jumlah & Prioritas \\
\hline Character & 0.424 & 0.518 & 0.383 & 0.321 & 0.294 & 1.94 & 0.388 \\
\hline Capacity & 0.212 & 0.260 & 0.383 & 0.321 & 0.294 & 1.47 & 0.294 \\
\hline Condition & 0.140 & 0.085 & 0.128 & 0.214 & 0.176 & 0.743 & 0.149 \\
\hline
\end{tabular}




\begin{tabular}{|c|c|c|c|c|c|c|c|}
\hline Capital & 0.140 & 0.085 & 0.064 & 0.107 & 0.176 & 0.572 & 0.114 \\
\hline Collateral & 0.085 & 0.052 & 0.042 & 0.035 & 0.059 & 0.273 & 0.055 \\
\hline
\end{tabular}

d. Menghitung matriks penjumlahan setiap baris

Untuk mendapatkan nilai matriks penjumlahan setiap baris, didapatkan dari data matriks perbandingan berpasangan antar kriteria dikalikan dengan nilai prioritas masing-masing kriteria pada matriks bobot nilai antar kriteria dan prioritas.

Sedangkan untuk mendapatkan nilai pada kolom jumlah dengan melakukan penjumlahan setiap nilai kriteria pada setiap baris. Sehingga diperoleh bobot masing-masing KPI adalah :

KPI Character $=0.388+0.776+1.164+1.164+1.94=5.432$

KPI Capacity $=(0.147+0.294+0.882+0.882+1.47=3.675$

Tabel 4.4 Nilai Bobot Masing-Masing KPI

\begin{tabular}{|c|c|c|c|c|c|c|}
\hline & Character & Capacity & Condition & Capital & Collateral & Jumlah \\
\hline Character & 0.388 & 0.776 & 1.164 & 1.164 & 1.94 & 5.432 \\
\hline Capacity & 0.147 & 0.294 & 0.882 & 0.882 & 1.47 & 3.675 \\
\hline Condition & 0.049 & 0.049 & 0.149 & 0.298 & 0.447 & 0.992 \\
\hline Capital & 0.377 & 0.377 & 0.057 & 0.114 & 0,342 & 1.267 \\
\hline Collateral & 0.011 & 0.011 & 0.018 & 0.018 & 0.055 & 0.113 \\
\hline
\end{tabular}

e. Penghitungan Rasio Konsistensi

Saaty [4] telah membuktikan bahwa indeks konsistensi dari matrik berordo $\mathrm{n}$ dapat diperoleh dengan rumus :

dimana: C.I = Indeks konsistensi

$$
\text { C. I }=\frac{\lambda \text { maks }-\mathrm{n}}{n-1}
$$

$\lambda$ maks $=$ Nilai eigen terbesar dari matriks berordo $n$

Nilai eigen terbesar didapat dengan menjumlahkan hasil perkalian jumlah kolom dengan menjumlahkan hasil perkalian jumlah kolom dengan eigen vector utama.

Tabel 4.5 Perhitungan Rasio Konsistensi

\begin{tabular}{|c|c|c|c|}
\hline & Prioritas & Jumlah & Hasil \\
\hline Character & 0.388 & 5.432 & 5.82 \\
\hline Capacity & 0.294 & 3.675 & 3.969 \\
\hline Condition & 0.149 & 0.992 & 1.141 \\
\hline Capital & 0.114 & 1.267 & 1.381 \\
\hline Collateral & 0.055 & 0.113 & 0.168 \\
\hline \multicolumn{3}{|c|}{ Jumlah } & $\mathbf{1 2 . 4 7 9}$ \\
\hline
\end{tabular}

Menggunakan tabel 3.3 dan tabel 3.5, nilai eigen terbesar yang diperoleh :

$$
\begin{aligned}
\lambda \text { maks } & =(\text { Jumlah } / \mathrm{n}) \\
& =12.479 / 4 \\
& =3,12
\end{aligned}
$$

Karena matrix berordo 5 (yakni terdiri dari 5 Kriteria Penilaian), nilai indek konsistensi yang diperoleh :

$$
\text { C. } I=\frac{3.12-5}{5}=-0,376
$$

Apabila C.I bernilai nol, berarti matrik konsisten. Batas ketidakkonsistensi yang ditetapkan Saaty, diukur dengan menggunakan Rasio Konsistensi (CR), yakni perbandingan indeks konsistensi dengan nilai pembangkit random (RI) seperti ditampilkan pada tabel berikut ini : 


\begin{tabular}{|c|c|c|c|c|c|c|c|c|c|c|}
\hline $\mathrm{n}$ & 1 & 2 & 3 & 4 & 5 & 6 & 7 & 8 & 9 & 10 \\
\hline R.I. & 0 & 0 & 0.58 & 0.9 & 1.12 & 1.24 & 1.32 & 1.41 & 1.45 & 1.49 \\
\hline
\end{tabular}

Dengan demikian, rasio konsistensi dapat dirumuskan :

Maka didapat :

$$
\mathrm{C} . \mathrm{R}=\frac{C . I}{R \cdot I}
$$

$$
\text { C. } R=\frac{-0,376}{1.12}=-0.336
$$

Karena $\mathrm{CR} \leq 0.1$ maka nilai perbandingan berpasangan pada matriks criteria yang diberikan konsisten. Jika CR tidak < 0.1, maka perlu diadakan kembali penilaian dengan menggunakan matriks berpasangan.

f. Menghitung nilai akhir untuk keputusan layak dan tidak layak debitur diberikan kredit

Langkah terakhir adalah pada hasil nilai prioritas KPI dan adanya konsistenan nilai dapat ditentukan proses nilai keputusan, yaitu dengan mengalikan nilai prioritas dengan data debitur. Sebagaimana digambarkan dalam tabel berikut ini :

Tabel 4.6 Menghitung Nilai Hasil Dengan Data Debitur

\begin{tabular}{|l|c|c|c|c|c|}
\hline \multirow{2}{*}{ Prioritas Kriteria } & Character & Capacity & Condition & Capital & Collateral \\
\cline { 2 - 6 } & $\mathbf{0 . 3 8 8}$ & $\mathbf{0 . 2 9 4}$ & $\mathbf{0 . 1 4 9}$ & $\mathbf{0 . 1 1 4}$ & $\mathbf{0 . 0 5 5}$ \\
\hline Sepriadi & 90 & 60 & 55 & 75 & 80 \\
\hline Sulastri & 85 & 55 & 75 & 80 & 95 \\
\hline Susi & 50 & 85 & 90 & 65 & 70 \\
\hline \multicolumn{5}{|l|}{} \\
\hline Sepriadi & Character & Capacity & Condition & Capital & Collateral \\
\hline Sulastri & 34,92 & 17,64 & 8,195 & 8,55 & 4,4 \\
\hline Susi & 32,98 & 16,17 & 11,175 & 9,12 & 5,225 \\
\hline
\end{tabular}

\begin{tabular}{|l|c|}
\hline \multicolumn{1}{|c|}{ Alternative } & Total \\
\hline Sepriadi & 73,705 \\
\hline Sulastri & 74,67 \\
\hline Susi & 69,06 \\
\hline
\end{tabular}

Nilai keputusan tergantung dari keinginan pemakai dalam mengambil keputusan, misalkan nilai $>=$ 70 dinyatakan layak kredit, jika $<70$ dinyatakan tidak layak mendapatkan kredit.

\section{Hasil dan Diskusi}

Pada tampilan awal dari program setelah di jalankan adalah tampilan Menu. Pada menu input terdapat 2 buah sub menu yaitu input data nasabah dan input data penilaian nasabah. Kemudian pada menu AHP terdapat 2 buah sub menu yaitu menu proses AHP, dan keputusan kredit. 


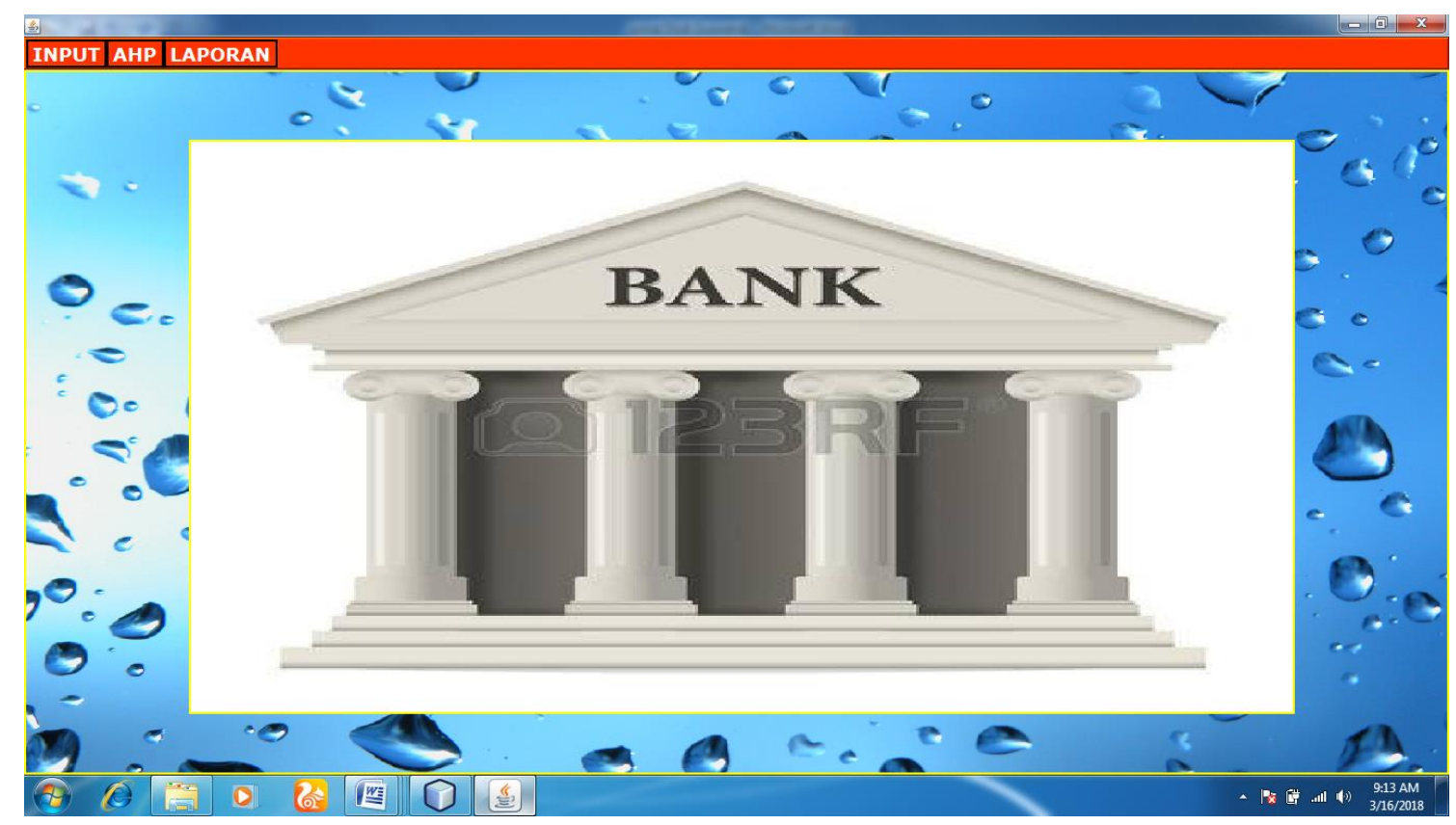

Gambar 5.1 : Form Menu Utama

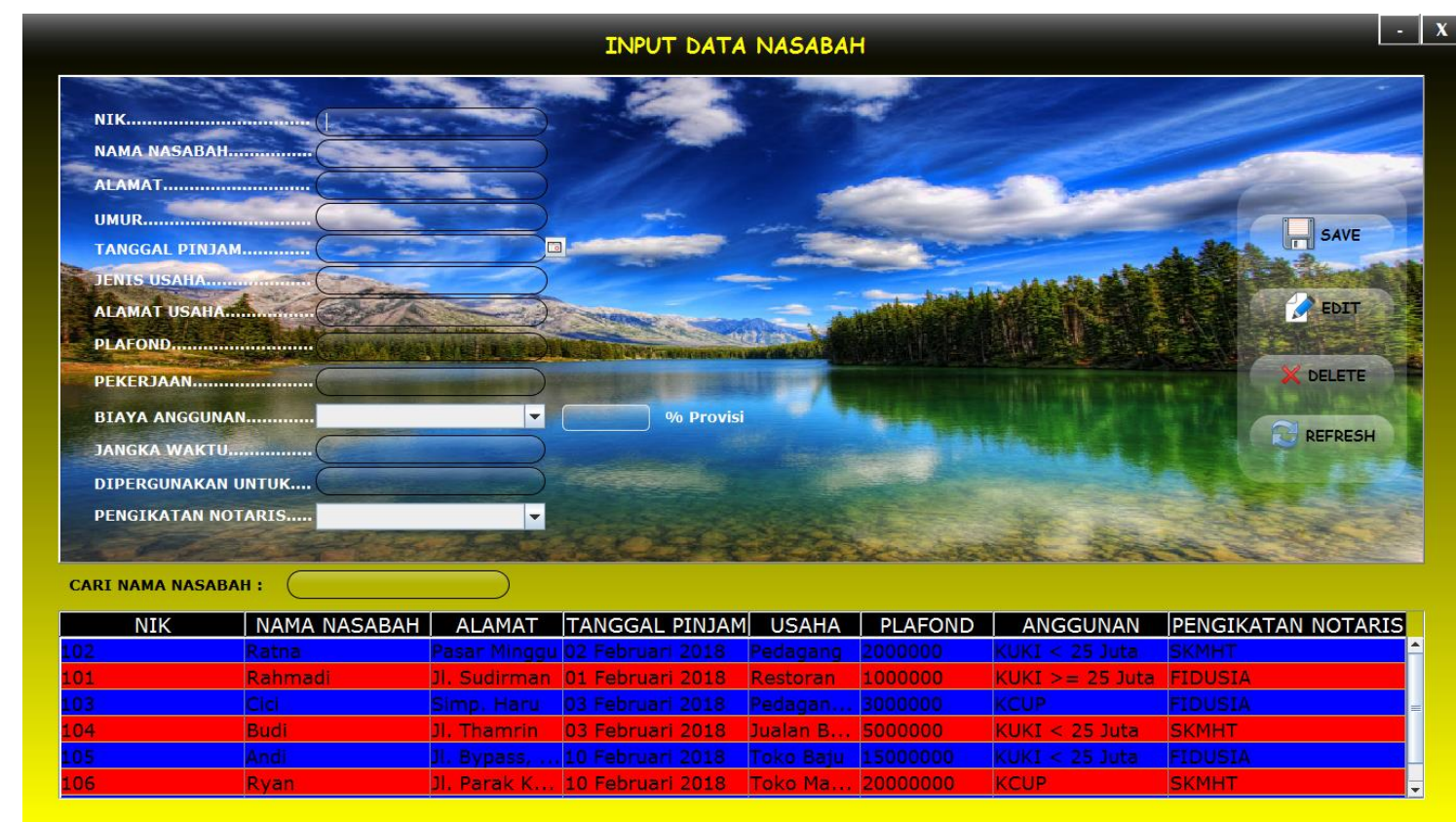

Gambar 5.2 : Form Input Data Nasabah

Tampilan Form input data nasabah berfungsi untuk menginput data-data nasabah ke database dengan primary key NIK. Data-data yang telah tersimpan ke database nantinya akan ditampilkan pada tabel. 


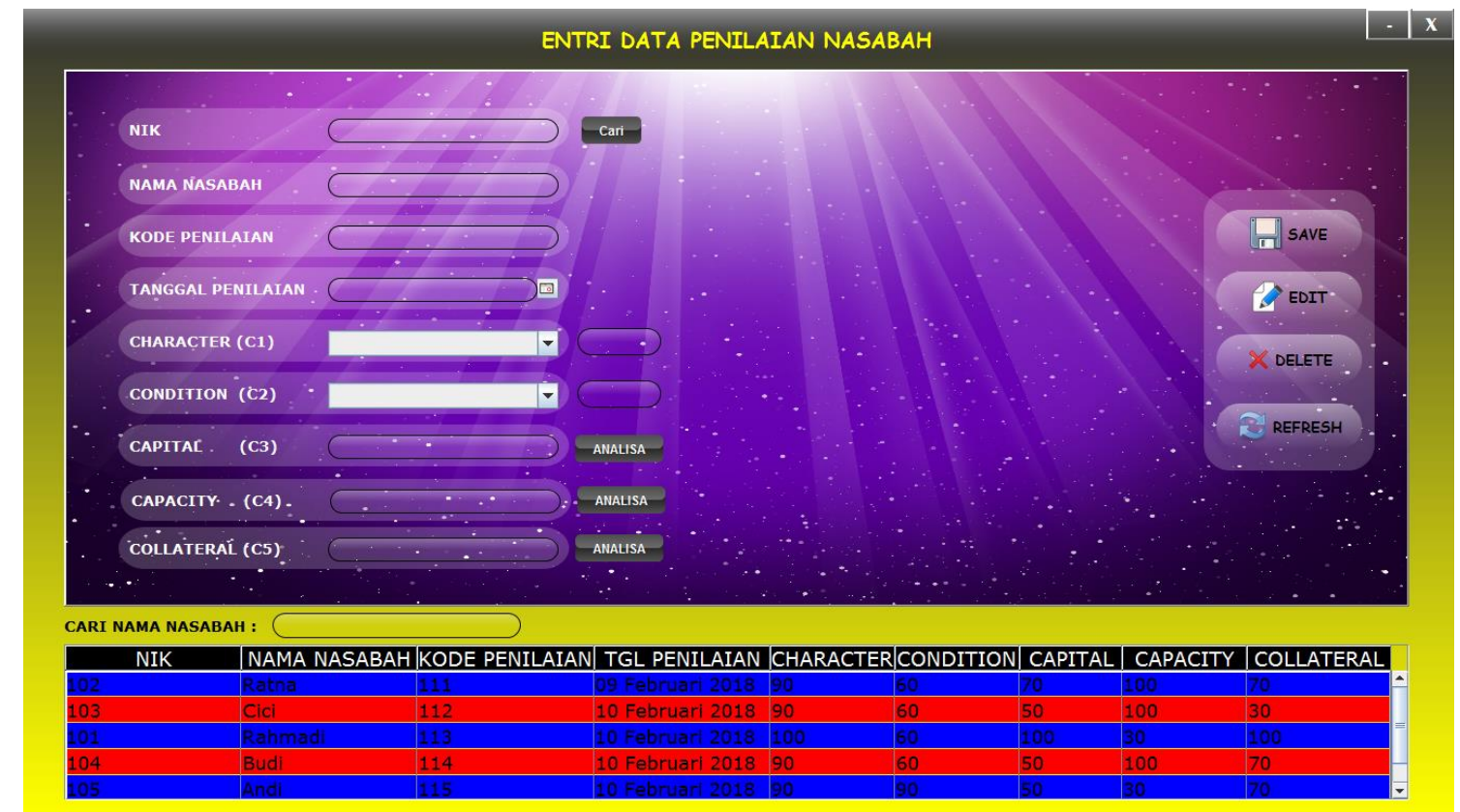

Gambar 5.3 : Form Penilaian Nasabah

Tampilan form Penilaian berfungsi untuk menginputkan data penilaian sesuai data nasabah yang ada dilapangan.

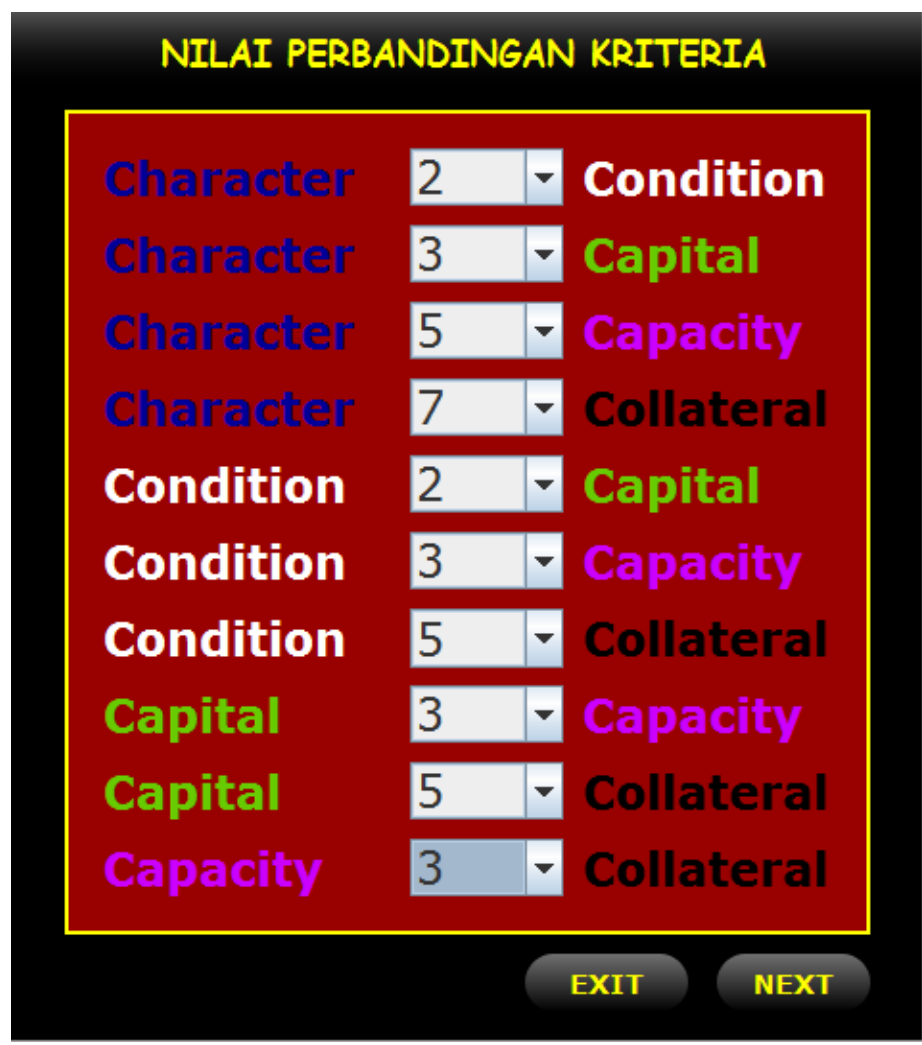

Gambar 5.4 : Form Perbandingan Kriteria 


\section{MATRIKS PERBANDINGAN KRITERIA}

\begin{tabular}{|c|c|c|c|c|c|}
\hline & Character & Condition & Capital & Capacity & Collateral \\
\hline Character & 1 & 2 & 3 & 5 & 7 \\
\hline Condition & 0.5 & 1 & 2 & 3 & 5 \\
\hline Capital & 0.33333334 & 0.5 & 1 & 3 & 5 \\
\hline Capacity & 0.2 & 0.33333334 & 0.33333334 & 1 & 3 \\
\hline Collateral & 0.14285715 & 0.2 & 0.2 & 0.33333334 & 1 \\
\hline JUMLAH & 2.1761904 & 4.0333333 & 6.5333333 & 12.333333 & 21 \\
\hline & & & & & NEX \\
\hline
\end{tabular}

Gambar 5.5 : Form Matriks Perbandingan Kriteria

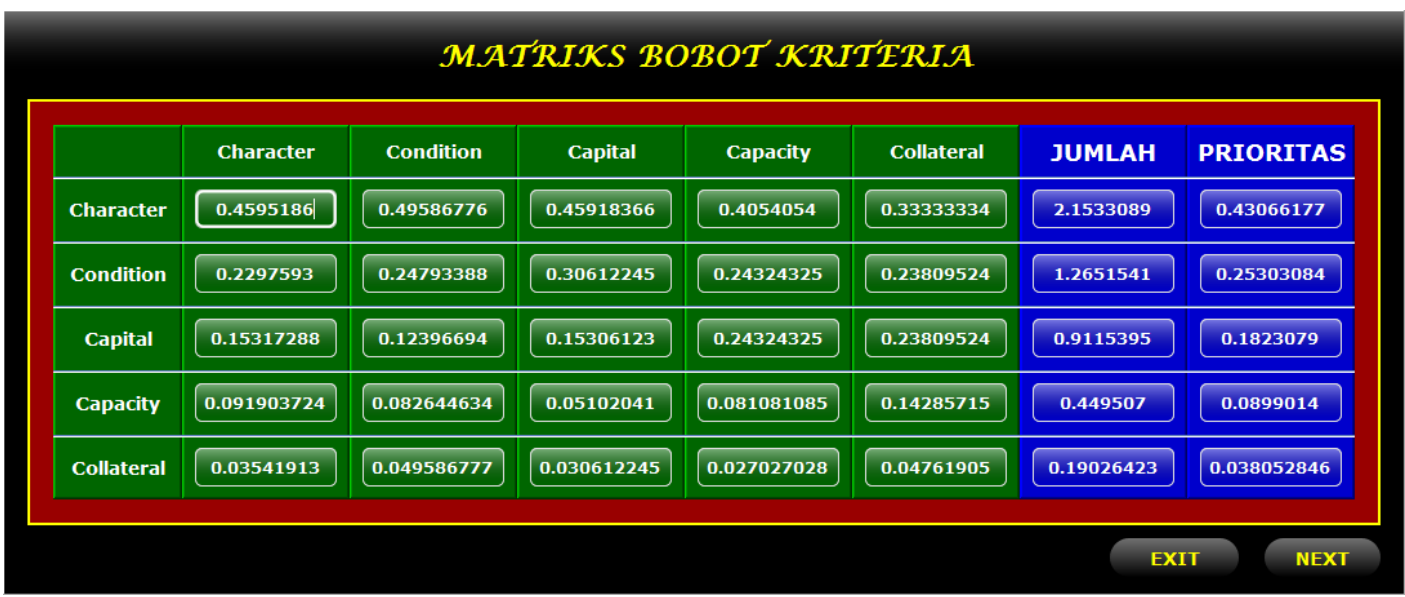

Gambar 5.6 : Form Matriks Bobot Kriteria

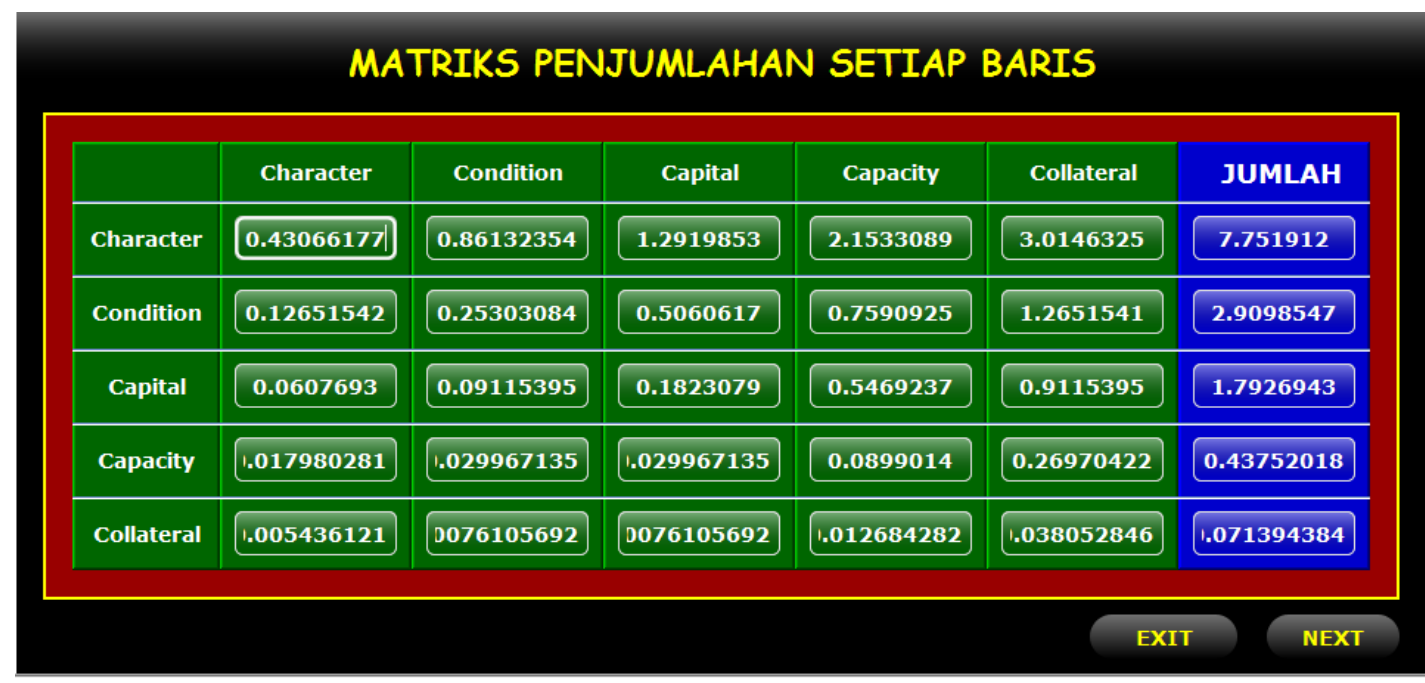

Gambar 5.7 : Form Matriks Penjumlahan Setiap Baris 


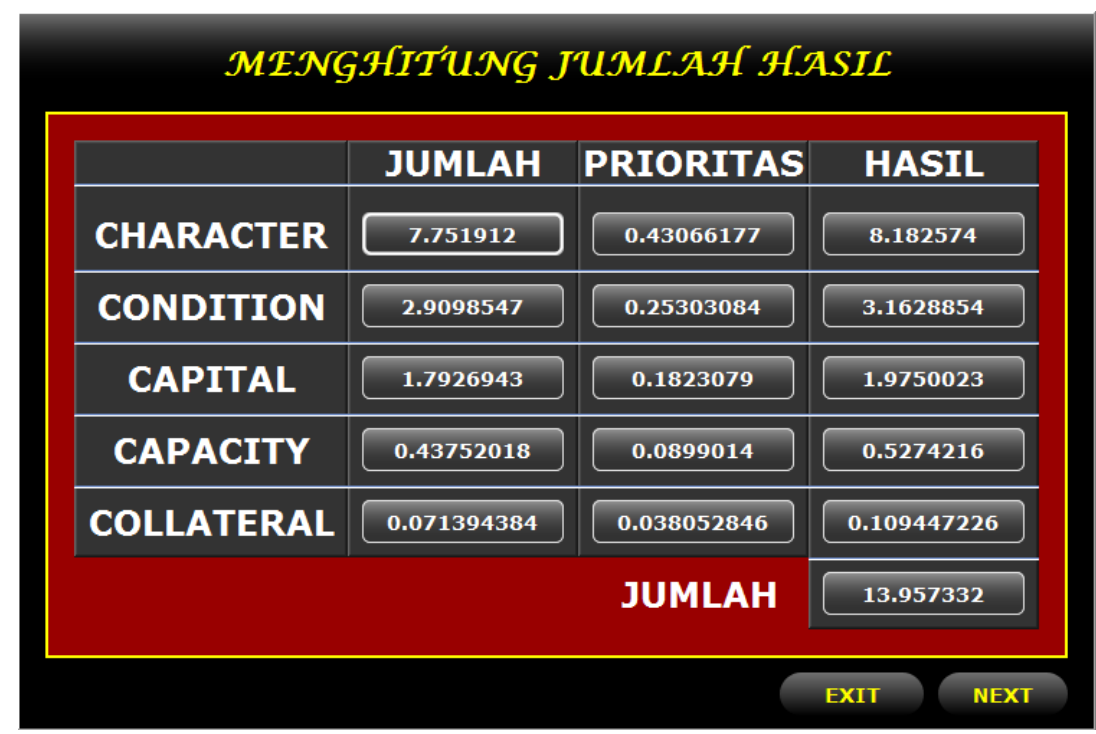

Gambar 5.8 : Form Jumlah

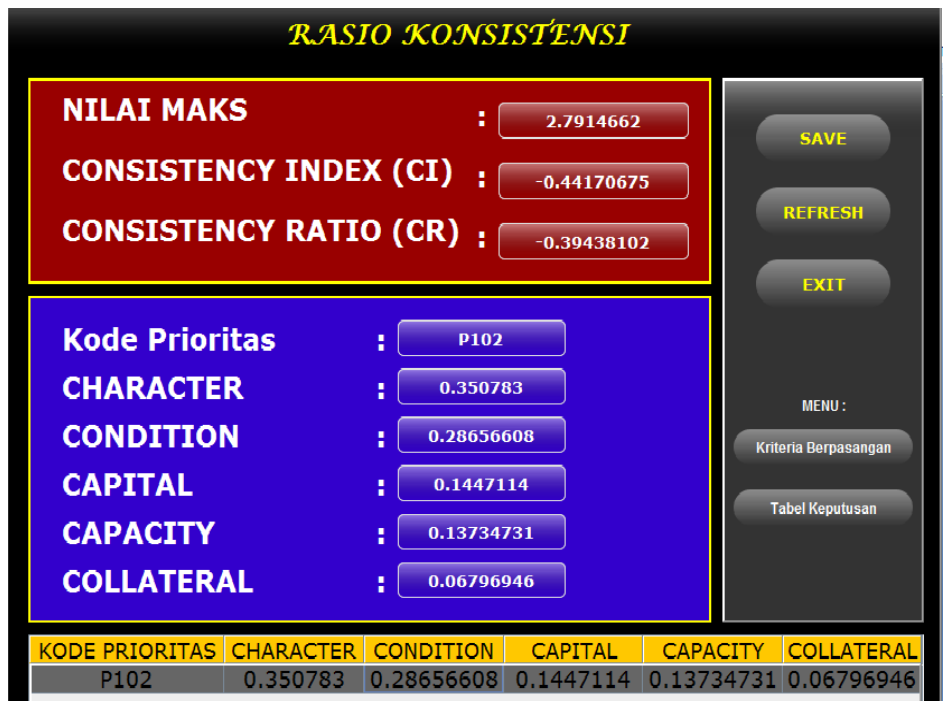

Gambar 5.9 : Rasio Konsistensi

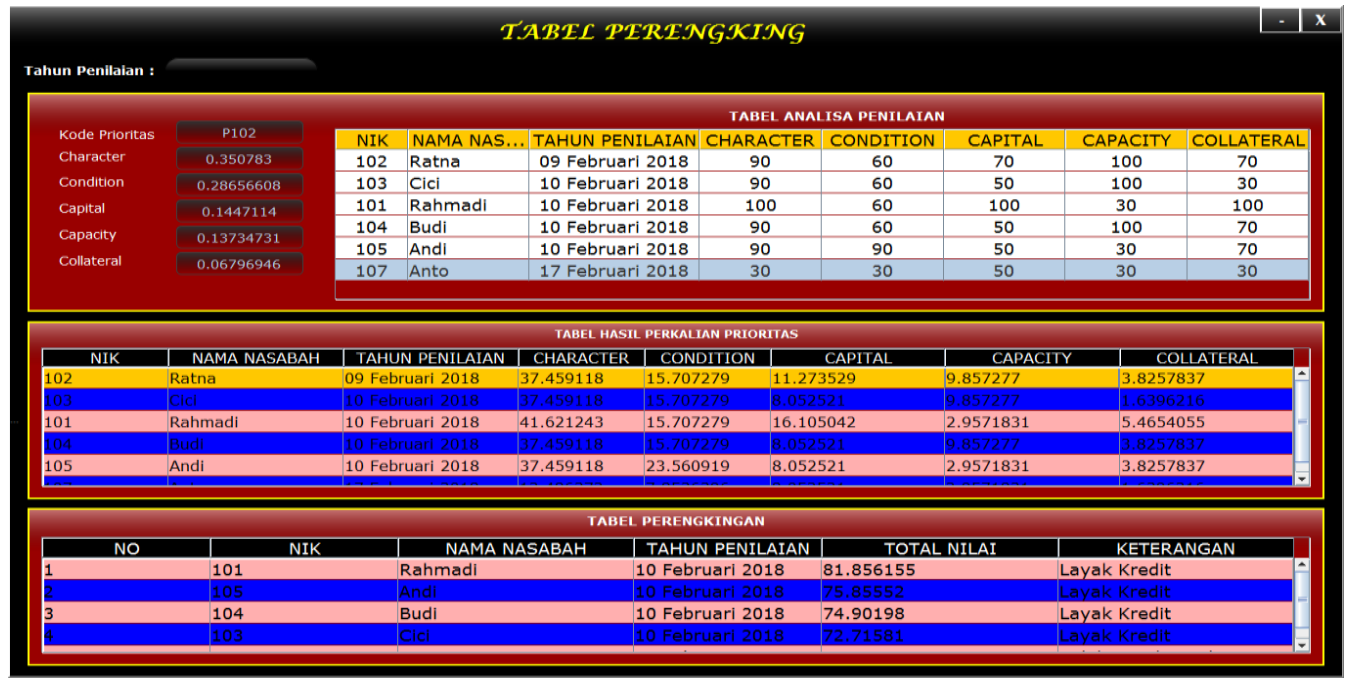

Gambar 5.10 : Form Perengkingan 


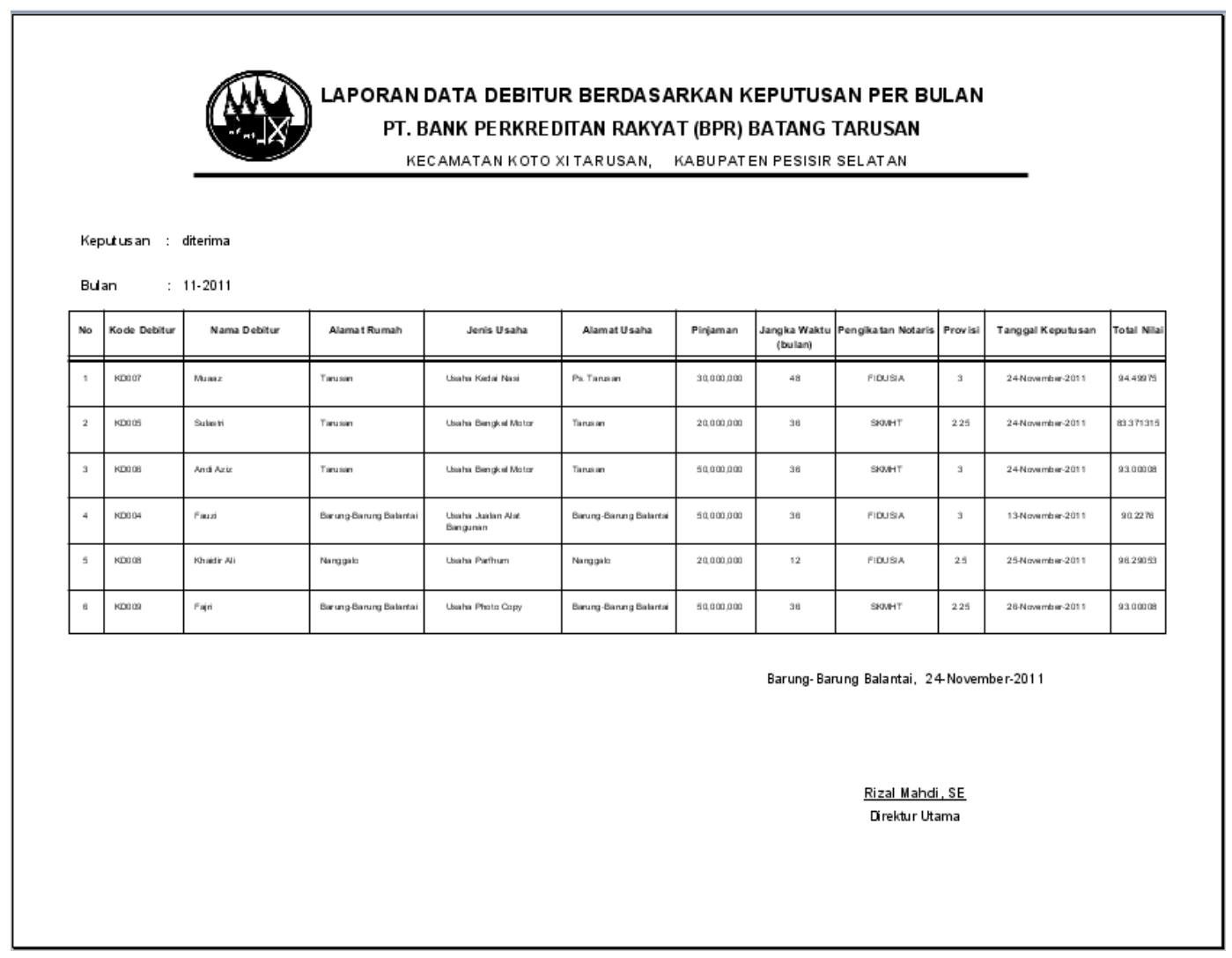

Gambar 5.11 : Perancangan Keputusan Per Bulan.

\section{Kesimpulan}

Setelah melakukan penelitian pada PT. Bank Perkreditan Rakyat (BPR) Batang Tarusan dan mempelajari segala aktifitas yang terjadi dalam sistem pengambilan keputusan data debitur dalam pemberian kredit kemudian mencoba menganalisa serta menguraikannya ke dalam skipsi ini, maka dari pembahasan bab-bab sebelumnya dapat ditarik kesimpulan, yaitu sebagai berikut:

1. Sistem pendukung keputusan yang selama ini masih dilakukan dengan manual sehingga banyak menimbulkan kelemahan dari segi keputusan yang tidak akurat, waktu dan informasi yang dihasilkan membutuhkan watu yang lama.

2. Dengan diterapkannya sistem baru ini diharapkan penggunaan komputer akan lebih lebih membantu dalam proses pengambilan keputusan serta pembuatan laporan yang dihasilkan akan lebih jelas dan terinci sehingga akan mempercepat proses mendapatkan informasi bagi perusahaan dan debitur.

3. Dengan menggunakan aplikasi bahasa pemograman Java dan didukung oleh database Oracle $10 \mathrm{~g}$ akan dapat mempermudah dan mempercepat dalam proses pengambilan keputusan.

\section{Referensi}

[1] Al Fatta, Hanif. 2007.Analisis Dan Perancangan Sistem Informasi. Yogyakarta : Andi Offset.

[2] Bambang, Wahyudi. 2004.Pengantar Struktur Data dan Algoritma. Yogyakarta : Penerbit Andi

[3] Binanto, Iwan. 2005. Konsep Bahasa Pemrograman. Yogyakarta : Andi Offset. 
[4] Hariyanto, Bambang. 2010. Esensi-Esensi Bahasa Pemrograman JAVA. Revisi Ketiga, Bandung : Informatika.

[5] HM, Jogiyanto. 2002.Analisis dan desain. Yogyakarta : Andi Offset.

[6] PC.S, Sutisno. 2006. Tangga-tangga waktu : Analytical Hierarchy Process (AHP). Teknodik (Online), http://en.wikipedia.org/wiki/Analytical Hierarchy Process, diakses 9 Agustus 2011.

[7] Victoria, Yurnadir. 2011. "Sistem Penunjang Keputusan Penerimaan Siswa Inklusi Anak Berkebutuhan Khusus pada SD Negeri 18 Koto Luar Kecamatan Pauh Padang dengan Menggunakan Bahasa Pemrograman Visual Basic 6.0." Skripsi Tidak diterbitkan Padang : Fakultas Ilmu Komputer Universitas Putra Indonesia "YPTK" Padang.

[8] Witarto. 2004. Memahami Sistem Informasi. Bandung : Informatika.

Yuliza, SY. 2009 "Pembangunan Sistem Pendukung Keputusan Untuk Evaluasi Kinerja Guru dengan Menggunakan Metode AHP.” Skripsi Tidak Diterbitkan. Padang : Fakultas Ilmu Komputer Universitas Putra Indonesia "YPTK" Padang.

[9] Shalahuddin, Mohammad. Rossa A.S. 2010. Pemrograman Berorientasi Objek. Bandung : Penerbit Modula.

[10] Kusrini. 2005. Dasar Pemrograman Java2. Yogyakarta: Andi Offset. 